Kong. Res. J. 1(2): 94-97, 2014

Kongunadu Arts and Science College, Coimbatore

\title{
SCREENING OF PHYTOCHEMICALS AND QUANTITATIVE ESTIMATION OF TOTAL FLAVONOIDS AND PHENOLIC COMPOUNDS OF LAGASCEA MOLLIS CAV. (ASTERACEAE)
}

\author{
Saradha, M., S. Paulsamy* and G. Abinaya \\ Department of Botany, Kongunadu Arts and Science College, Coimbatore - 641029. \\ *E.mail: paulsami@yahoo.com
}

\begin{abstract}
Aim of the study was to analyze the phytochemical constituents and estimation of total flavonoids and phenolic compounds of leaves and roots of the medicinal plant Lagascea mollis. Methanol extract of dried leaves and roots of L. mollis was prepared by using soxhlet apparatus. The extract prepared was tested for preliminary qualitative phytochemical screening, followed by the quantitative estimation of total flavonoids and phenols by spectroscopy. The selected plant parts were found to contain alkaloids, flavonoids and terpenoids in both parts and saponin is present only in leaf. In quantitative estimation the reports revealed the presence 0.017 and $0.013 \mathrm{mgRE} / \mathrm{g}$ extract and 458.91 and $704.50 \mathrm{mgGAE} / \mathrm{g}$ extract total flavonoids and phenolic compounds in leaf and root extract respectively. These major phytoconstituents present in this species may be accounted as factors for the medicinal importance of L. mollis.
\end{abstract}

Keywords: Lagascea mollis, Asteraceae, flavonoids, phenols.

\section{INTRODUCTION}

Medicinal plants that have at least one of their parts are being (leaves, stems, barks or roots) used for therapeutic purposes (Bruneton, 1993). World plant biodiversity is the largest source of herbal medicine and still about $60-80 \%$ of world population rely on plant based medicines which are being used since the ancient ages as traditional health care system. India is endowed with rich wealth of medicinal plants, which ranked our country in the list of top producers of herbal medicine. In response to the increased popularity and greater demand for medicinal plants, a number of conservation groups are recommending that wild medicinal plants be brought into cultivation (Aqil et al., 2006). It is now clear that, the medicinal value of these plants lies in the bioactive phytochemical constituents that produce definite physiological effects on human body. Phytochemicals are responsible for medicinal activity of plants (Savithramma et al., 2011), these are non-nutritive chemicals that have protected human from various diseases. Phytochemicals are basically divided into two groups that are primary secondary metabolites based on the function in plant metabolism. Phytochemical constituents are the basic source for the establishment of several pharmaceutical industries. The constituents are playing a significant role in the identification of crude drugs (Savithramma et al., 2011). The main purpose of the present study was to evaluate the presence of various phytochemicals and quantitative estimation of flavonoids and phenols in leaf and root extract of Lagascea mollis.

Lagascea mollis belongs to the family, Asteraceae, commonly known as Seruppadithazhai, Kenathuppoondu in Tamil is native to tropical America. The leaf paste of this plant is given to cuts and wounds. Flowers are given for ear complaints. It helps to control noxious weeds, serve as animal fodder and safe to grow with corn and beans (Alarcon et al., 2007; Koche et al., 2008). It is reported to have antibacterial activity and isolation of flavonol, glyacoside, patulitrin and isopatulitrin as well as dehydrofalcarinone (Chourasia and Rao, 1987; ElNagar and Doskotch, 1979; Bohlmann et al., 1962), ensures the antimicrobial property.

\section{MATERIALS AND METHODS}

\subsection{Collection of plant material}

The leaf and roots of Lagascea mollis plant were collected from the vicinity of Coimbatore, Tamil Nadu.

\subsection{Preparation of extract}

The samples were dried at room temperature and further ground in a mortar. About 20 of each part of plant powder was extracted in 100 $\mathrm{mL}$ of methanol by soxhlet apparatus. The solvent was concentrated at temperature below $40^{\circ} \mathrm{C}$ and the resulting extracts were used for determination of phytochemicals. 


\subsection{Phytochemical screening}

The extracts were subjected to preliminary phytochemical tests to determine the groups of secondary metabolites present in the plant material as follows:

\subsubsection{Detection of alkaloids (Ciulci, 1994)}

To $1 \mathrm{~mL}$ of each extract, 2-3 drops of Dragendorff's and Meyer's reagents were separately added. An orange red precipitate/turbidity with Dragendorff's reagent or white precipitate with Meyer's reagent would indicate the presence of alkaloids.

\subsubsection{Detection of flavonoids (Sofowora, 1993)}

To the $4 \mathrm{ml}$ of each part of the plants extract, a piece of magnesium ribbon was added followed by concentrated $\mathrm{HCl}$ drop wise. A colour ranging from crimson to magenta indicated the presence of flavonoids.

2.3.3. Detection of glycosides (Gokhale et al., 2008)

Keller Kiliani test: To the $2 \mathrm{~mL}$ of extracts, $1 \mathrm{~mL}$ of glacial acetic acid with ferric chloride and concentrated sulphuric acid were added. The appearance of blue colour indicates the presence of glycosides.

\subsubsection{Detection of saponins (Brain and Turner, 1975)}

One ml of extract was taken in a test tube and $5 \mathrm{~mL}$ of distilled water was added and vigorously shaken. A persistent froth that lasted for at least 15 minutes indicated the presence of saponins.

2.3.5. Detection of tannins (Mace and Gorbach, 1963; Ciulci, 1994)

Two $\mathrm{ml}$ of the extracts were diluted with distilled water in separate test tubes and 2-3 drops of $5 \%$ ferric chloride $\left(\mathrm{FeCl}_{3}\right)$ solution was added. A green-black or blue-black colouration indicates the presence of tannins.

\subsubsection{Detection of steroids (Ciulci, 1994)}

Two $\mathrm{mL}$ of the extracts were taken in separate test tubes and evaporated to dryness. The residues were dissolved in acetic anhydride followed by the addition of chloroform. Concentrated sulphuric acid was added by the side of the test tube. Formation of brown ring at the interphase of the two liquids and the appearance of violet colour in the supernatant layer indicated the presence of steroids.
2.3.7. Detection of terpenoids (Salkowski and Balish, 1991)

Five $\mathrm{mL}$ of extracts were mixed with $2 \mathrm{~mL}$ of chloroform and concentrated $\mathrm{H}_{2} \mathrm{SO}_{4}$ to form a layer. A reddish brown coloration of the interface shows the presence of terpenoids.

\subsubsection{Detection of phenols (Krishnamoorthy, 1988)}

Five $\mathrm{ml}$ of the concentrated extracts were taken and $2 \mathrm{~mL}$ of neutral ferric chloride solution was added. Appearance of violet colour indicates the presence of phenols.

\subsection{Quantitative phytochemical analysis}

\subsubsection{Determination of total flavonoids}

The total flavonoid content of samples was determined by following the modified colorimetric method of Zhishen et al. (1999). $0.5 \mathrm{ml}$ extract was mixed with $2 \mathrm{~mL}$ of distilled water and subsequently with $0.15 \mathrm{~mL}$ of $5 \% \mathrm{NaNO}_{2}$ solution. After $6 \mathrm{~min}, 0.15$ $\mathrm{mL}$ of $10 \% \mathrm{AlCl}_{3}$ solution was added and allowed to stand for $6 \mathrm{~min}$, then $2 \mathrm{~mL}$ of $4 \% \mathrm{NaOH}$ solution was added to the mixture. Immediately distilled water was added to bring the final volume to $5 \mathrm{~mL}$, and then the mixture was thoroughly mixed and allowed to stand for another $15 \mathrm{~min}$. Absorbance of the mixture was recorded at $510 \mathrm{~nm}$ versus prepared water blank. Rutin was used as a standard compound for the quantification of total flavonoid. All the values were expressed as milligram of rutin equivalent (RE) per gram of extract.

\subsubsection{Determination of total phenolics}

The total phenolic content was determined according to the method described by Siddhuraju and Becker (2003). Aliquots of each extract were taken in test tubes and made up to the volume of 1 $\mathrm{mL}$ with distilled water. Then $0.5 \mathrm{~mL}$ of folinciocalteu phenol reagent (1:1 with water) and $2.5 \mathrm{~mL}$ of sodium carbonate solution (20\%) were added sequentially in each tube. Soon after vortexing the reaction mixture, the test tubes were placed in dark for $40 \mathrm{~min}$ and the absorbance was recorded at $725 \mathrm{~nm}$ against the reagent blank. The analysis was performed in triplicate and the results were expressed as gallic acid equivalents (GAE).

\section{RESULTS AND DISCUSSION}

The extractive values, colour and the per cent yield of the leaves and roots of Lagascea mollis are given in Table 1 . The present study carried out on the plant samples revealed the presence of medicinally active constituents. The phytochemical characters of $L$. mollis were investigated and 
presented in Table 2 . The results showed the presence of alkaloids, flavonoids and terpenoids in both parts and saponin in leaves only. These are the main constituents responsible for the therapeutic value of the medicinal plants (Hussain et al., 2011). According to Ayodele (2003) diverse use of plants in the treatment of wide variety of diseases are attributable to the presence of the phytochemicals. Phytochemicals are secondary metabolites produced and used by the plants for protection and repair the processes within the natural environment. Phenols, flavonoids and tannins are good antioxidant substances which have been reported to have antidiarrhoeal activity also (Agbor et al., 2004) and prevent or control oxidative stress related disorders (Vinson et al., 1995).

Total flavonoids and phenolic content of leaves and roots of $L$. mollis in rutin and gallic acid equivalents are presented in Table 3. 0.017 and $0.013 \mathrm{mgRE} / \mathrm{g}$ extract, 458.91 and $704.50 \mathrm{mgGAE} / \mathrm{g}$ extract flavonoids and phenols were present in leaves and roots respectively. The flavonoids are hydroxylated phenolic substances known to be synthesized by plants in response to microbial infection and they have been found to be antimicrobial substances against wide array of microorganisms in vitro. Their activity is probably due to their ability to complex with extracellular and soluble proteins and to complex with bacterial cell wall (Marjorie, 1996.). They are also effective antioxidants and show strong anticancer activities (Salah et al., 1995; Del-Rio et al., 1997; Okwu, 2004). The phenolic compounds are one of the largest and most ubiquitous groups of plant metabolites (Singh et al., 2007). They possesses biological properties such as antiapoptosis, antiaging, anticarcinogen, antiinflammation, antiatherosclerosis and cardiovascular protection and improvement of endothelial function as well as inhibition of angiogenesis and cell proliferation activities (Han et al., 2007). Several studies have described the antioxidant properties of medicinal plants which are rich in phenolic compounds (Brown and Rice-Evans, 1998; Krings and Berger, 2001).

The results revealed the presence of medicinally important constituents such as flavonoids and phenol in the study plant. Further the plant could be considered for antioxidant, anticancer, immunomodulatory activities.

\section{REFERENCES}

Agbor, A.G., L. Talla and J.Y. Ngogang, (2004). The Antidiarrhoeal activity of Alchornea cordifolia leaf extract. Phytother Res. 18(11):873-876.
Alarcon, S.R., L.S.N. Ocampos, L.V. Flores Galleuillo, A. Pacciaroni and V.E. Sosa, (2007). phytochemistry and phytotoxicity activity of Lagascea mollis (Asteraceae). The journal of tye Argentine Chem Soc. 95(1-2):25-31.

Aqil, F., I. Ahmed and Z. Mehmood, (2006). Antioxidant and free radical scavenging properties of twelve traditionally used. Indian medicinal plants. Turk J Biol. 30: 177-183.

Ayodele, S.Q. (2003). The effects of herbal remedies. Paper presented at the 12th Annual Conference of Botanical Society of Nigeria, University of Logos, South Africa.

Bohlmann, F., C. Arndt, H. Bornowski, H. Jastrow and K.M. Kleine, (1962). Chem Ber. 95:1320

Brain, K.R. and T.D. Turner, 1975. The Practical Evaluation of Phytopharmaceuticals. Wright Scientechica, Bristol pp.57-58.

Brown, J.E. and C.A. Rice-Evans, (1998). Luteolin rich artichoke extract protects low density lipoprotein from oxidation in vitro. Free Radical Res. 29: 247-255.

Bruneton, J. (1993). Plants medicinales: Phytochimie, Pharmacognosie. Zema. New York. lavoisier: P.914, (Fre).

Chourasia, O.P. and J.T. Rao, (1987). Anti bacterial Efficacy of Some Indian Essential Oils, Perfumery and Cosmetic. Perfume and Cosmetic 68(9): 564-66.

Ciulci, I. (1994). Methodology for the analysis of vegetable drugs. Chemical industries Branch, Division of Industrial Operations. UNIDO, Romania 24:26 - 67.

Del-Rio, A., B.G. Obdululio, J. Casfillo, F.G. Main and A. Ortuno, (1997). Uses and properties of citrus flavonoids. J. Agric. Food Chem. 45: 4505-4515.

ElNagar, S.F. and R.W. Doskotch, (1979). Patulitrin and Acetyl Patulitrin, Flavonol Glycosides From Lagascea mollis . J. Nat Prod. 42(2):126-28.

Gokhale, S.B., C.K. Kokate and A.P. Purohit, (2008). $A$ text book of phrmacognosy, Nirali Prakashan, Maharashtra, India pp: 889.

Han, X., T. Shen, and H. Lou (2007). Dietry polyphenols and their biological significance. Int. J. Mol. Sci. 950-988.

Hussain, I., N. Khan, R. Ullah, Shanzeb, S. Ahmed, FA. Khan and S. Yaz, (2011). Phytochemical, physiochemical and anti-fungal activity of 
Eclipta alba. African J Pharm Pharmacol. 5(19), pp. 2150-2155.

Koche, D.K., R.P. Shirsat, S. Imran, M. Nafees, A.K. Zingare and K.A. Donode, (2008). Ethnomedicinal survey of Nagzira Wild lLIfe Sanctury, District Gondia (M.S) India-Part II. Ethnobotanical Leaflts 12:532-537.

Krings, U. And R.G. Berger, (2001). Antioxidant activity of roasted foods. Food Chem. 72: 223229.

Krishnamoorthy, K.V. (1988). Botanical Histochemistry, Viswanathan Publishers, Chennai.

Mace and S.L. Gorbach, (1963). Anaerobic bacteriology for clinical laboraties pharmacognosy. 23:89-91.

Marjorie, C. (1996). Plant products as antimicrobial agents. Clinical Microbiol. Rev. 12: 564-582.

Okwu, D.E. (2004). Phytochemicals and vitamin content of indigenous species of southeastern Nigeria. J.Sustain. Agric. Environ. 6(1): 30-37.

Salah, N., N.J. Miller, G. Pagange, L. Tijburg, G.P. Bolwell, E. Rice and C. Evans, (1995). Polyphenolic flavonoids as scavenger of aqueous phase radicals as chai breaking antioxidant. Arc. Biochem. Broph. 2: 339-346.

Salkowski, C.A. and E. Balish, (1991). Role of natural killer cells in resistance to systemic cryptococcosis. J Leukoc Biol. 50(2):151-159.

Savithramma, N., M. Linga Rao and D. Suhrulatha, (2011). Screening of medicinal plants for secondary metabolites. Middle-East Journal of Scientific Res., 8: 579-584.

Siddhuraju, P. and K. Becker, (2003). Antioxidant properties of various solvent extracts of total phenolic constituents from three different agroclimatic origins of Drumstick tree (Moringa oleifera Lam.) leaves. J Agricul Food Chem. 51(8): 2144 - 2155.

Singh, R., S.K. Singh and S. Arora, (2007). Evaluation of antioxidant potential of ethyl acetate extract/fractions of Acacia auriculiformis A. Cunn. Fod Chem. Toxicol., 45: 1216-1223.
Sofowora, A. (1993). Medicinal plants and Traditional Medicines in Africa. Spectrum Books Ltd., Ibadan, Nigeria. 2: 81-85.

Vinson, J.A., Y.A. Dabbagh, M.M. Serry and J. Jang, (1995) .Plant flavonoids, especially tea flavonoids are powerful antioxidant using an invitro antioxidant model for heart disease. $J$. Agric Food Chem. 43: 2800-2802.

Zhishen, J., T. Mengcheng and W. Jianming, (1999). Research on antioxidant activity of flavonoids from natural materials. Food Chem. 64: 555559.

Table 1. Extractive values of the methanolic leaf and root extracts of Lagascea mollis.

\begin{tabular}{ccccc}
\hline S.No. & Parts & Colour & $\begin{array}{l}\text { Weight of crude } \\
\text { extracts(g)/20g } \\
\text { plant materials }\end{array}$ & yield \\
\hline 1. & Leaves & Dark & 3.68 & 18.4 \\
2. & Roots & Eregh & 2.81 & 14.05 \\
& & brown & & \\
\hline
\end{tabular}

Table 2. Phytochemical screening of the methanolic leaf and root extracts of Lagascea mollis.

\begin{tabular}{cccc}
\hline \multirow{2}{*}{ S.No. } & \multirow{2}{*}{ Tests } & \multicolumn{2}{c}{ Parts used } \\
\cline { 3 - 4 } & & Leaves & Roots \\
\hline 1. & Alkaloids & +++ & +++ \\
2. & Flavonoids & +++ & +++ \\
3. & Glycosides & - & - \\
4. & Saponin & +++ & - \\
5. & Tannin & - & - \\
6. & Steroids & - & - \\
7. & Terpenoids & ++ & +++ \\
8. & Phenols & - & - \\
\hline
\end{tabular}

Table 3. Estimation of total flavonoids and phenolic content of methanolic leaf and root extracts of Lagascea mollis.

\begin{tabular}{cccc}
\hline $\begin{array}{c}\text { S. } \\
\text { No }\end{array}$ & Parts & $\begin{array}{c}\text { Total Flavonoids } \\
\text { mg RE/g extract }\end{array}$ & $\begin{array}{c}\text { Total Phenolics } \\
\text { mg GAE/g extract }\end{array}$ \\
\hline 1. & Leaves & $0.017 \pm 0.002$ & $458.91 \pm 6.53$ \\
2. & Roots & $0.013 \pm 0.005$ & $704.50 \pm 20.40$ \\
\hline
\end{tabular}

GAE - Gallic acid equivalent, RE - Rutin equivalent.

Values are expressed as mean $\pm \operatorname{SD}(n=6)$. 